\section{Academic Freedom: A Realistic} Appraisal

\section{PHILIP G. ALTBACH}

Philip G. Altbach is a Monan University Professor and director of the Center for International Higher Education at Boston College. E-mail: altbach@bc.edu.

$\mathrm{E}$ veryone seems to favor academic freedom. Indeed, if university leaders or ministers of education were asked, they would claim that this privilege is universally practiced. Yet, problems concerning academic freedom exist almost everywhere-created by changing academic realities, political pressures, growing commercialization and marketization of higher education, or legal pressures. The purpose of this article is to argue that academic freedom needs to be carefully defined so that it can be defended in the global climate of complexity. A new, and probably more delimited, understanding of academic freedom is needed in the age of the Internet and the global knowledge economy

\section{A BIT OF HISTORY}

Academic freedom has a long history in higher education but has always been contested by forces outside the university. Since the time of Martin Luther and Socrates, professors have been persecuted for their views-by state or religious authorities or by powerful interest groups who do not like dissenting views or uncomfortable truths. Modern academic freedom was perhaps first codified by Wilhelm von Humboldt when he developed the research university in Berlin in I8I8. The German academic freedom idea was limited in scope. It included Lehrfreiheit-the freedom of professors to teach in their classrooms and to do research in the direct areas of expertise. The Humboldtian ideal did not include freedom to express views outside the professor's area of expertise and I 9 th-century Germany often disciplined academics who expressed dissenting opinions about politics and excluded socialists or other dissenters from holding academic appointments. It should also be noted that students were guaranteed Lernfreiheit - the freedom to study what they wished.

The American Association of University Professors (AAUP) first focused on academic freedom in I9I5, and its statement emphasized three main principles: "to promote inquiry and advance the sum of human knowledge," "to provide general instruction to the students," and "to develop experts for various branches of the public service." With the agreement of university presidents, the AAUP expanded the purview of academic freedom in I940 to include professorial expression on topics outside of the direct academic expertise of the professor. In other words, professors had a wider range of freedom of expression, although the statement emphasizes professorial responsibility and recognizes some restrictions. In both the
German and American cases, academic freedom included protection of academic appointments through a tenure system: professors could not be fired for their research or views on a range of topics. Professors came to be protected in roles as members of the academic community as well. They could not be disciplined because they might oppose university leadership on issues relating to academic governance of policy. This broader definition, stemming from both German and American traditions, seems to be widely accepted globally in countries that have a traditional commitment to academic freedom, although it is possible to point to many violations of the accepted norms.

\section{CONTEM PORARY CONFUSION}

At the same time, definitions about academic freedom are being expanded and contracted beyond generally accepted norms. Some now define academic freedom as virtually everything that permits effective teaching and research-faculty involvement in governance, adequate budgets for academic institutions, suitable conditions for teaching and learning such as appropriate classrooms and access to technology. This stretches academic freedom to include everything necessary for a successful university. At the other end of the spectrum, some countries or universities claim adherence to academic freedom where there are policies in place that restrict what can be taught in the classroom or on themes for research and publication.

Contemporary realities have also created complexities. The Internet, distance education, and related technological innovations, as well as the rise of multinational media conglomerates that increasingly control the distribution of knowledge, have raised questions about the ownership of knowledge. Issues related to academic freedom are involved in these technological debates.

Academic freedom has a long history in higher education but has always been contested by forces outside the university.

Is academic freedom a necessary condition for high-quality "world-class" universities today? The evidence seems to show the requirement. The various international rankings of universities give those institutions with a high degree of academic freedom the top scores. Few highly ranked universities systematically violate traditional norms of academic freedom. A high degree of academic freedom is particularly important for the social sciences and humanities, but all fields benefit from freedom of inquiry and a sense that the university is committed to the free expression of ideas.

\section{THE NEED FOR A NEW CONSENSUS}

Academic freedom is without question a core value for higher education. In the knowledge economy of the 2Ist century aca- 
demic freedom needs some rethinking, with all of the pressures on higher education engendered by massification, commercialization, and accountability. What is needed is a return to the core concepts of academic freedom developed by von Humboldt and expanded in the AAUP's I940 statement. Academic freedom, after all, is the right of professors to teach without constraint in their field of expertise, do research and publish, and express themselves in the public space (newspapers, the Internet, and so on). Academic freedom generally protects the employment of professors as well as providing the most ironclad guarantees possible - through a formal tenure or civil service system, or other arrangements.

Professors came to be protected in roles as members of the academic community as well. They could not be disciplined because they might oppose university leadership on issues relating to academic governance of policy.

A statement issued by professors at the University of Cape Town in South Africa and quoted in a famous I957 United States Supreme Court decision states:

It is the business of a university to provide that atmosphere which is most conducive to speculation, experiment and creation. It is an atmosphere in which there prevail "the four essential freedoms" of a university-to determine for itself on academic grounds who may teach, what may be taught, how it shall be taught, and who may be admitted to study.

These ideals neatly summarize many of the essential ideas of academic freedom.

Academic freedom does not essentially concern how universities are managed, whether they are adequately funded or even how the faculty is compensated. Academic freedom does not ensure that professors have a role in governance but should guarantee that they can speak out on internal management issues without fear of sanction. Academic freedom does not relate to accountability. Universities may legitimately demand appropriate productivity from faculty members. Professors' work may be evaluated, and inadequate performance may lead to sanctions or even, in extreme cases, firing, but only after careful procedures that do not violate academic freedom. Academic freedom protects professorial freedom of teaching, research, and expression—and nothing else.

\section{CURRENT PROBLEMS}

Traditional academic freedom is under threat in many places today, creating the need for more attention to be paid to contemporary challenges. These crises range from professors being subject to severe sanctions for their teaching, research, or expression-including firing, jail, or even violence. Groups like Scholars at Risk provide assistance to such academics and publicize their problems. In some countries, restrictions exist on what can be researched, taught, and published. In some cases the restrictions are explicit, but in most cases the "red lines" that cannot be crossed are not clearly spelled out. Yet, academics may be sanctioned if they violate these terms.

The list of such countries and fields of inquiry is unfortunately rather long. In the United States, which has in general effective protections for academic freedom, problems are emerging. Courts have recently ruled that academics who speak out against the policies of their own universities and are penalized for such actions are not protected by academic freedom. The growing number of part-time teachers in many countries have no effective protection of their academic freedom, since they are often employed for just one course or for a short and often indeterminate period of time. The ownership of knowledge by multinational corporations or even by employing universities has become an issue of contention in some countries. Is it a violation of academic freedom for an external organization to control publication through ownership rights? Is academic freedom violated if governments impose curricular requirements of various kinds, as is the case in a significant number of countries? In short, academic freedom is under considerable stress today, and expanding the definition of this key concept to include basically everything makes the protection of the essentials of academic freedom increasingly difficult. The complexities of the 2ist century require careful attention to the core principles of academic freedom so that they can be protected in an increasingly difficult environment.

\section{New Challenges to Academic Freedom in the United States}

\section{ROBERT M. O'NEIL}

Robert M. O'Neil is former president of the University of Virginia and the University of Wisconsin system, recently retired as professor of law at Virginia, and currently directs both the Thomas Jefferson Center for the Protection of Free Expression and the Ford Foundation's Difficult Dialogues Initiative. E-mail: rmo@virginia.edu.

A cademic freedom in American higher education evolves in curious and often unpredictable ways. For those who teach at public or state-supported institutions, the courts play a major role in defining the scope of such freedom. For faculty at independent or private colleges and universities, whose policies are seldom subject to court review, standards are provided by organizations such as the American Association of 